\title{
UNESCO Inclusion Policy and the Education of School Students with Profound Intellectual and Multiple Disabilities: Where to Now?
}

\author{
Gordon Lyons, Michael Arthur-Kelly \\ Centre for Special Education and Disability Studies, School of Education, University of Newcastle, Newcastle, \\ Australia \\ Email: gordon.lyons@newcastle.edu.au
}

Received 29 January 2014; revised 28 February 2014; accepted 7 March 2014

Copyright (C) 2014 by authors and Scientific Research Publishing Inc.

This work is licensed under the Creative Commons Attribution International License (CC BY). http://creativecommons.org/licenses/by/4.0/

(c) (i) Open Access

\begin{abstract}
The education of school students with profound intellectual and multiple disabilities presents diverse challenges to practitioners, families and policymakers. These challenges are philosophically and ethically complex, and impact curriculum, assessment and pedagogy. Given the international ascendancy of both the UNESCO Policy Guidelines on inclusion in education and the principles of inclusion for people with disabilities with respect to human services policy and practice, the authors build on their previous work to advocate for renewed debate about the nature of school education for these students, and put forward four pathways to inform this debate.
\end{abstract}

\section{Keywords}

Inclusion, Profound Intellectual and Multiple Disabilities, School Education

\section{Introduction}

Students with profound intellectual and multiple disabilities (PIMD; this being the preferred term of the International Association for the Scientific Study of Intellectual and Developmental Disabilities) are amongst the wider population of individuals usually referred to as having severe intellectual disabilities, high support needs and/or complex needs. These students typically have an untestable IQ and present with a diversity of intellectual, physical, sensory and communicative impairments. School education is mostly offered in "special" classes and schools. 
Teaching students with PMID is considered to be difficult because these students often find learning more challenging than others (Foreman \& Arthur-Kelly, 2005; Imray, Gazquez, \& Bond, 2010). This presents a complexity of opportunities for teachers and others at the classroom, school, home, jurisdictional and political levels. Families and carers, unlike those of most students, are more frequently involved in determining the nature of their children's education, especially in terms of preparation for lifelong learning and participation (ArthurKelly, Foreman, Bennett, \& Pascoe, 2008). Policy makers struggle with contradictions explicit in the regularspecial education nexus (Sailor, 2008; Slee, 2011). And for many others interested in the broader inclusion debate, individuals with PIMD often just don't “fit” common generalisations about and accommodations for persons with less severe and less complex disabilities (Imray et al., 2010). These challenges commonly invoke broad philosophical and ethical debate (Slee, 2011; Stolk, Boer, \& Seldenrijk, 2011) and more specific debate around curriculum assessment and pedagogy (Imray et al., 2010).

Overall though, social justice arguments for the right of children with PIMD to have access to some form of school education are generally accepted (Imray et al., 2010; UNESCO, 2009), notwithstanding that the nature of this school education, particularly setting options, curriculum, pedagogy and assessment, is historically contentious (Ware \& Donnelly, 2004). The emergence and now contemporary preeminence of the principles of inclusion for people (of all ages) with disabilities (of all "types") across community milieus generally, and the UNESCO Policy Guidelines on Inclusion in Education (UNESCO, 2009), throw a broader spotlight on these issues.

The history of school education for students with PIMD is a relatively short one and demonstrates the many disadvantages, inequities and challenges faced by this group of students; particularly with respect to access and participation, curriculum, assessment and pedagogy. An appreciation of this history contextualizes and informs debate about possible future "best" pathways for the education of these students (see Lyons and Cassebohm (2012) for a comprehensive review). In current times, various international proclamations and statements of understanding inform national policies and practices that impact persons with disabilities generally, and children with PIMD specifically. Some of these (e.g. the UNESCO 1948 Universal Declaration of Human Rights, the 1980 Convention against Discrimination in Education, the 1989 Convention on the Rights of the Child, the 1994 UNESCO Salamanca Statement and Framework for Action in Special Needs Education, and the 2006 Convention on the Rights of Persons with Disabilities (UNESCO, 2009)) demonstrate strong international political commitment; at least in principle. More recently the UNESCO 2009 Policy Guidelines on Inclusion in Education has emerged as the most pertinent development in this field (European Agency for Development in Special Needs Education, 2009). Clearly, international consensus is that students with disabilities have the same rights as others to a fair and meaningful education (Slee, 2011).

Now in the early 21st century, inclusion and its underlying principles present as the preeminent ideology guiding human support services for people with disabilities generally, and education specifically; at least in the international arena and in more affluent countries (Bain \& Lancaster, 2006). Inclusion principles (as they apply to education) advocate the need for collaboratively negotiated, inclusive but differentiated approaches to placement, curriculum, pedagogy and assessment for students with additional needs arising from disabilities (and indeed for students with special educational needs arising from other challenges) (Ferguson, 2008). Policy and practice initiatives and changes supporting the inclusion principles (for students with disabilities) continue to gain traction through legislative and policy developments across various national Government jurisdictions (UNESCO, 2009).

Notwithstanding substantial consensus in the international arena, wherein the rationale for students with PIMD to be educated has emerged out of the abovementioned declarations, the nature of education for students with PIMD within and across nations varies widely, primarily due to the aforementioned fiscal and human resource constraints. Indeed, despite the evidently encouraging international consensus that inclusion is the most influential contemporary philosophy, practices vary widely and are generally less inclusive than the philosophy and rhetoric suggest (Slee, 2011).

Curriculum, pedagogy and assessment are generally acknowledged as the three key interdependent elements in school education for all students (Brady \& Kennedy, 2010). Examinations of and/or changes to one element usually suggest or require the same in the other two (Ewing, 2010). To preface debate on the education of students with PIMD it is important to at least preview the nature of these three key elements as they affect these students. 


\section{Curriculum}

On the topic of curriculum, mainstreaming and integration policies and (placement) practices now "compete” with inclusion-oriented policies and practices; notwithstanding the resilience of the regular-special education nexus (Slee, 2008). Consequently interpretations of "functionality" (with respect to applied life skills) have shifted to at least segue with mainstream curriculum. This helps mainstream teachers to better understand the needs of their students with disabilities and to facilitate the integration of students with (at least) less severe intellectual disabilities (Westwood \& Graham, 2003). This also means that special education teachers have to modify their functional curricula to embrace mainstream curricula (Nietupski et al., 1997). Individualized Education Plans typically still address the more atypical curriculum components for students with PIMD like individualized behaviour, therapy and primary care programs but these plans are most often seen as "special education business" (Jones, 2010). This has the potential to compromise the impetus for mainstream teachers to take more appropriate programming and instructional responsibility for these students (Ryndak et al., 2008).

Facilitating students with PIMD to engage with regular curricula is for many mainstream teachers still "just too hard” and so the tensions between teachers, theorists and policymakers have, in many jurisdictions, firmed (Konza, 2008). Although there have been some successes with early intervention initiatives and programs in preschool settings, the aforementioned tensions continue and become exacerbated as students progress through school (Imray et al., 2010). In some educational regions around the world some sound "alternative” curricula designed specifically for high school students with less severe intellectual disabilities who are progressing towards transition to the workplace have emerged but these are inappropriate for most students with PIMD. Notwithstanding these and other areas of contention, two areas of consensus around curriculum have emerged: the need to develop both communication and social skills. This better enables students with PIMD to communicate their internal states (needs, wants and preferences), and consequently to the moderation of various challenging behaviours (Balandin \& Duchan, 2007; Barber, 2011).

Educational authorities in many jurisdictions responded to challenges through the development of national curriculum initiatives. In Great Britain these included the English P Levels (Qualifications and Curriculum Development Agency, 2011), the Northern Ireland Quest for Learning initiative (Government of Ireland, 2006) and Welsh Routes for Learning initiative (Welsh Assembly Government, 2006a, 2006b). These resources guide teachers in developing curricula, and individualized instructional programs for students (with PIMD) who are generally unable to meet more prescriptive requirements (Government of Britain, 2009). (Note: As Pepper (2007) points out, these initiatives highlight the critical interrelationships between curriculum, pedagogy and assessment.) In Australia a new national curriculum for all students is now being progressively implemented, although students with PIMD will still mostly have a collaboratively negotiated individualized education program (IEP) based on their additional educational needs (Dowrick, 2002). In Australia most students with PIMD are educated in special schools (Dempsey, 2014), perhaps because divergent interest groups still support different placement priorities for a variety of reasons (e.g. Foreman \& Arthur-Kelly, 2014; Rogers, 2007; Soresi, Nota, \& Wehmeyer, 2011). (Note: Under Australian law placement options are restricted if an enrolment involves a reasonable expectation of unjustifiable hardship arising from excessive resource demand and/or deleterious infringement on the educational opportunities of other students. National and state disability legislations (the 1992 Disability Discrimination Act and 2005 Disability Standards for Education) apply here (NSW Disability Discrimination Legal Centre Inc., 2010).)

The nature and state of "advancement” of school education (and indeed other human support services) for children (young people and adults) with PIMD varies widely across countries. Much of this variation is due to the range of economic milieus in and across countries (UNESCO, 2009). The focus of this paper is more on school education policy and practices in countries which (arguably) have the financial and human resources needed to implement their national (and other jurisdictional) policy and practices around students with PIMD. Many countries have best (policy) intentions but lack the resources necessary to substantially act on these. Clearly it is not our intention to be critical in this case. Nevertheless lessons can be learned from history, and from the present practices of others; even those practicing in very different sociopolitical and economic contexts.

\section{Pedagogy}

As for curriculum above, the principles of inclusion have taken philosophical precedence in regard to the policy 
around and pedagogy of teachers educating students with disabilities, and international consensus (clearly evident in the aforementioned UNESCO promulgations) has guided policy shifts towards more universal, inclusive curricula. Indeed "differentiation” (Foreman \& Arthur-Kelly, 2014) and "Universal Design for Learning” (Hall, Meyer, \& Rose, 2012) are key terms in contemporary pedagogical vernacular. Special educators are now called upon to share their specialized pedagogical knowledge with mainstream teachers who are progressively required to teach students with intellectual disabilities in mainstream settings.

Notwithstanding that teaching students with PIMD is still widely regarded to be "special education business" (Jones, 2010), there is a growing professional awareness that good differentiated pedagogy is, generally speaking, good for all students (Dixon \& Verenikina, 2007; UNESCO, 2008). Whole class-oriented pedagogy still mostly prevails in most mainstream classrooms for mainstream students but differentiated (individualized) pedagogies and programming drawing on the principles of Universal Design for Learning (Hall, Meyer, \& Rose, 2012) are now acknowledged as evidence-based practice for students with additional needs (Snell, 2008). This has provided the focus for objections put by many mainstream teachers when asked/told to integrate students with disabilities who claim they just don't have the time or expertise to deliver the quality of instruction required (Konza, 2008). This would especially apply for students with PIMD.

Another major pedagogical development to impact students with PIMD has been a refocusing on instructional activities around building communication and social skills (Hewett, 2009). Students with PIMD are mostly pre-intentional communicators, and efficacious instruction does require specialized pedagogical content knowledge and skills (Imray, 2011).

Over the last decade "evidence-based practice" has emerged as a leading objective for educational research, policy and practice development. Consequently there has been a resurgence in professional interest in examining and improving pedagogy (Hattie, 2012; Rowe, 2006; UNESCO, 2008). It is widely acknowledged that teaching quality (pedagogy) is the strongest variable affecting learning quality; particularly in school education (Hattie, 2012) and special (and mainstream) education increasingly benefit from the emerging consensus about the nature and qualities of evidence-based practice (Carter, Stephenson, \& Strnadova, 2011). Watershed conceptualizations of evidence-based school teaching practice like Authentic Pedagogy (Newman et al., 1996) are not intended as exclusive of any student groups, but their relevance to students with PIMD was and is still debated. Stephenson (2006), for example, argues that the "intellectual quality” focus of the NSW Quality Teaching model of pedagogy (which is based on the Authentic Pedagogy model) has clear relevance to the development of cognitive and communication skills in students with PIMD. Formosa and Dixon (2004) represent the opposing view, that is, that it has little relevance to these students.

\section{Assessment}

Students with PIMD benefit from a very student-centered (individualized) education, so curriculum pedagogy and assessment requirements for individual and small groups of students with PIMD are often unique and rely on considerable (student-centered) expertise and knowledge (Bray et al., 1988). Discussions about assessment then are essential (Browder, Spooner, \& Bingham, 2004). Both formative and summative assessment procedures are requisiteas assessments variously informs student program reviews, learning outcome priorities and achievement benchmarks at the individual, group and cohort levels as well as providing evidence for teaching efficacy reviews (Donnelly, 2005).

For most students, broad achievement benchmarks like end-of-term reports and national competency testing scores are reasonably indicative of individual and cohort progress (Watkins, 2007). For students with PIMD though a diversity of curriculum-based assessments is critical to inform evidence-based practice and achieve best learning outcomes (Arthur-Kelly \& Neilands, 2014; Dowrick, 2002). These students often have idiosyncratic learning needs. Their learning progress is usually incremental so frequent regular and strategic individualized (data-based) assessments are essential (Bray et al., 1988). For decades now, highly trained special educators have used incremental performance data to guide their instructional progress; informed by their training in Applied Behaviour Analysis. Indeed, special educators spearheaded the development of curriculum-based assessment and programming, now widely recognized as evidence-based practice (Arthur-Kelly \& Neilands, 2014).

Contemporary international proclamations, like the preeminent UNESCO 2009 Inclusion Policy Guidelines, clearly advocate an inclusive approach to the teaching (and assessment) of all students. Evidently, at least in the 
international milieu, the principles of inclusion primarily inform policy and practice development in the education of students with disabilities (Slee, 2011).

There remain, nevertheless, considerable challenges to achieving an "authentic" inclusive approach to education at the individual country level; particularly in regard to assessment. The UK National Curriculum faced such a challenge (Imray et al., 2010), wherein the Welsh and Irish governments developed alternative "prefoundation" assessment scales for those students (with PIMD) who were unable to achieve the first level of competency (Government of Britain, 2009). Consequently more assessment guidelines were developed to enable comparisons around learning outcomes (Loftus et al., 2005). In the United States the requirement for all students to be performance benchmarked on common assessment scales has brought considerable criticism from those who doubt their validity (Qualifications and Curriculum Development Agency, 2009). In Australia, as in many countries, inconsistent interpretations of pertinent government legislation meant that educational policies and practices at state, regional and local levels were quite divergent (NSW Disability Discrimination Legal Centre, 2010; Sigafoos et al., 2010).

For students with PIMD, evidence-based assessment is not the norm (Carter et al., 2011) and a variety of restraints and barriers are complicit to this situation. See (Australian Teacher Education Association, 2006; Konza, 2008; Slee, 2008; Forlin et al., 2009). Given that the education of most students with PIMD is focused on achieving goals in an Individualized Education Plan, the purpose and authenticity of comparative assessment certainly appears questionable (Imray et al., 2010).

\section{Where to Now?}

Authentic inclusion; in human services generally and in the education of students with disabilities more specifically, prevails as a goal to which most nations aspire, but inadequate fiscal and human resources and diverse policy interpretations mean that it is an unlikely outcome for many. For many students with PIMD, who are amongst the most difficult children to educate, authentic inclusion is even more unlikely. Curriculum, pedagogy and assessment policy and practices around these students is clearly complicated, and given that equally contrasting national legislative and policy contexts prevail (Browder et al., 2006; Dixon \& Verenikina, 2007), consistent and widespread evidence-based practice is not likely while the "status quo" remains (Imray et al., 2010). Best practice now calls for research-based evidence to inform the development of each of these three key elements of education to achieve the best educational outcomes for students with PIMD.

Notwithstanding the abovementioned challenges to the education of students with PIMD; especially around inclusion generally, and curriculum pedagogy and assessment policies and practices specifically, there is a considerable knowledge base about what is needed to improve educational outcomes for students with disabilities (Arthur \& Foreman, 2002; Australian Association of Special Education, 2010; Opertti \& Belalcazar, 2008). This is informed by a reasonable research base identifying evidence-based initiatives impacting the inclusive education of students with disabilities, some of which has relevance to students with PIMD. These evidence-based initiatives include for example: systematic, data-based instruction and assessment; augmentative and alternative communication technologies; collaborative consultation; student-centered planning; behaviour state assessment; Applied Behaviour Analysis and Positive Behaviour Support; curriculum-based assessment and programming; school renewal; more "flexible" government funding; increased professional development for educators; a curricula focus on communication and social skills development; differentiation; and Universal Design for Learning (Foreman \& Arthur-Kelly, 2014; Hall, Meyer, \& Rose, 2012; Konza, 2008; Lyons \& Cassebohm, 2011).

From an international perspective most students with PIMD, if they have access to any school education, are educated in "special” schools or classes by "special” educators (Imray et al., 2010). Although some national and state jurisdictions have taken the initiative to deliver educational services under one (authentically) inclusive milieu (e.g. Finland), "special education" and its infrastructure prevails. Most students with PIMD have an individualized needs-based teaching/learning program delivered in accordance with their Individualized Education Plan but this often relates little to the "common" curriculum mandated for the vast majority of students.

The nature of school education for children with disabilities generally, and students with PIMD specifically, is contentious; particularly in the context of the principles of inclusion (Australian Association of Special Education, 2011; Simmons \& Bayliss, 2007; Slee, 2011; Smith, 2007; UNESCO, 2009). Intended educational outcomes for students with PIMD are often so individual and their post-school lives so different from those discussed for most of their age peers (due to their lifelong dependence in all activities of daily living) that it has 
been conjectured that the nature of their education needs to be fundamentally different to that of other students (Lyons, 2003).

What might the ("best") futures be for these children in diverse jurisdictions across the world? What issues might inform debate about possible new directions and developments in the education of these children? In the next section the authors put forward four potential pathways for the school education of children with PIMD (adapted and extended from Lyons and Cassebohm, 2012). There are other pathways of course, but these four provide readers with a range of options for facilitating and informing debate about the future of school education for children with PIMD.

\section{The Authentic Inclusion Pathway}

This pathway leads to placement of all students with PIMD in regular neighborhood classes in fully inclusive school systems with some individual/group withdrawal for focused teaching/learning activities. Curriculum, pedagogy and assessment practices would be differentiated to meet the individual needs of all students in each class/cohort (consistent with the principles of Universal Design for Learning), and additional support provided to address issues of equity and access. External benchmark assessments would be modified for individual students with appropriate "accommodations". This pathway aligns authentically and closely with the UNESCO inclusion policy guidelines and is philosophically and ethically equitable.

In many countries (especially those less affluent), the previously listed restraints and barriers are likely to slow progress along this pathway; the goal though remains authentic. Some jurisdictions have already achieved this goal. A small number of Scandinavian countries generally practice "full" educational and social inclusion. The Finnish Government for example reports that the "state of inclusion (at least in terms of school education) has already been achieved" (Saloviita, 2009), although external special education services still support some students (Karakoski, 2008)). The choice of this pathway would likely have substantial "in principle" professional and community support (Dixon \& Verenikina, 2007, Cook et al., 2000) but at the same time be heavily criticized by a "pragmatic" opposition who reason that the abovementioned restraints and barriers are resilient and insurmountable; and the pathway and goal unrealistic (Scruggs \&Mastropieri, 1996).

\section{The Strategic Inclusion Pathway}

This pathway leads to placement of all students with PIMD in "base" special classes in regular local schools in fully inclusive school systems with strategic engagement with regular classes. A broader interpretation of "least restrictive environment" (Taylor, 1988) applies here. Curriculum, pedagogy and assessment practices in the base special class would be developed within an Individualized Education Plan context and in regular class engagement within a differentiated context. Additional supports would be provided to address issues of equity. External benchmark assessments would be modified for individual students with appropriate "accommodations". This pathway aligns partly with the UNESCO inclusion policy guidelines. As with the authentic inclusion pathway above, various restraints and barriers would hinder progress, but maybe less so than in the case of the first pathway. There are broad precedents for taking this pathway. In the USA, for example, federal government legislation effectively mandates inclusion "in the least restrictive environment" along with the provision of an appropriately negotiated and resourced Individualized Education Plan (Boyd et al., 2005). This pathway should have strong "in principle" community and political support but would also be resisted by a "pragmatic" opposition of educationalists who might reason (as is the case for the authentic inclusion pathway) that the abovementioned restraints and barriers are resilient and insurmountable; and hence the pathway and goal is unrealistic.

\section{The Opportunistic Inclusion Pathway}

This pathway leads to placement of all students with PIMD in classes in segregated special schools with (only) opportunistic engagement in regular neighborhood school education activities and curriculum, pedagogy and assessment practices on a student-by-student basis. A less progressive interpretation of "least restrictive environment" applies here. Curriculum, pedagogy and assessment practices in the special school class would be developed within an evidence-based practice Individualized Education Plan context, and any regular neighborhood school engagement and additional supports would be provided to facilitate enhanced achievement of Individualized Education Plan goals/outcomes. External benchmark assessments would not apply. This pathway hardly 
aligns with the UNESCO interpretation of inclusion. Restraints and barriers would variously impact progress. There are precedents for taking this pathway. In the UK and Australia there is a "cascade" of placement options for students with PIMD including regular class, special class and (mostly) special school placements. The countries of the UK have their own curriculum, but in recognition of the failure of these to meet the needs of students with PIMD, they have developed and introduced common curricula and assessment guidelines specifically for these students. These guidelines (i.e., the English "P” Levels, the Welsh Routes for Learning documents, and Northern Ireland's Quest for Learning documents) "preface” the national curricula. In Australia similar tensions have accompanied the development and implementation of the new national curriculum.

By way of illustration with respect to these complex debates, Britain appears to be placing an increasing number of students with PIMD in residential special schools (Simmons \& Bayliss, 2007). This would lead to the (re)segregation of students with PIMD in residential schools (McGill, Tennyson, \& Cooper, 2006) wherein a “24/7 Individualized Education Plan (IEP)” would be implemented across school, home and community settings. Clearly there would be (and are) widely opposing philosophical opinions on such a placement and on 24/7 IEPs for students with PIMD notwithstanding that residential special schools are quite common in some European countries. Residential special schools are indeed an emerging phenomenon in Great Britain, and advocate support is based on addressing "the best interests" of the students and their families (McGill, Tennyson, \& Cooper, 2006). In this pathway, the main variables are placement and pedagogy, although curriculum and assessment might not change.

\section{The Quality of Life Pathway}

This pathway leads to all school students with PIMD becoming involved in what would probably be a very different curriculum, with concomitantly different pedagogy and assessment. This pathway takes an alternative approach to curriculum design and development involving a significant restructuring of curriculum, pedagogy and assessment practices to align with the principles of quality of life (QOL) referenced human service delivery (Lyons \& Cassebohm, 2012; Schalock, 2010). Proponents argue that the overarching goal of education for students with PIMD should be to improve their current and future QOL by providing them with educational experiences and instruction which would improve their ability to experience life satisfaction, happiness and fun.

There is wide support in the extant literature for this QOL perspective (and theory) in the broader human services sector (especially with respect to persons with disabilities) (Shearer, 2010), as well as practice precedents in the school education sector (Bayliss, 2005; Longhorn, 2002; Ware \& Donnelly, 2004). Bayliss (2005), for example, describes initiatives taken by a group of UK special schools for students with PIMD to introduce curricula specifically focused on QOL development. Education curriculum documents worldwide often include a preface of overarching educational goals that refer to improving the overall QOL of students, albeit usually with a future orientation as an outcome of the "whole" schooling experience. School systems (with government funding support) are taking an increasing interest in teaching about student happiness and wellbeing, often within the broader context of values education (Morris, 2009; Pagliano, 2006; Smith, 2010). Happiness, wellbeing and QOL are also emerging as guiding principles in the development of human support services for adults with intellectual disabilities (See e.g. Brown, Schalock, \& Brown, 2009; Lyons, 2010; Schalock, 2010; Vos et al., 2010).

A QOL focus can guide IEP (and person-centered planning) for students (and adults) with PIMD (Lyons \& Cassebohm, 2010). Proponents agree that pertinent developmental and functional curricula elements would still be included in any IEP/person-centered plan but that a clearer and more emphatic focus on QOL improvement should prevail (Ware \& Donnelly, 2004). This pathway could have strong "in principle” support from a diversity of interest groups.

When parents are asked what they want/wish for their children (particularly parents of children with PIMD) they most often reply, "We just want him/her to be happy". Proponents of this pathway argue (not unlike most others) that school education is about preparing children and young people for responsible adulthood in order that they become the most capable and contributing member of society that individual can be. Given that children with PIMD are extremely unlikely to grow up to be other than totally or predominantly carer dependent, an appropriate emphasis should be placed on learning to be happy. In 2003 Lyons introduced the idea of a "Functional curriculum" for school students with PIMD (Lyons, 2003). In this context, the QOL pathway appears to be well placed to help prepare children with PIMD for a better present and future. 


\section{Conclusion}

The school education of children with PIMD continues to pose substantial philosophical, ethical, pragmatic and practical challenges for educators, families and policymakers, particularly given the ascendancy of the UNESCO (2009) Policy Guidelines on Inclusion in Education. The nature of school education for these students is complicated by the regular-special education nexus debate (Foreman \& Arthur-Kelly, 2014; Lyons \& Cassebohm, 2012), a consequence of the too short history of education for this small and very diverse group. These students appear to be the "odd ones out" in school education, not just with respect to inclusion, but also more specifically with respect to curriculum, pedagogy and assessment. What does the future hold for school students with PIMD? If educational jurisdictions take different pathways (with respect to inclusion) how might these impact these students, and their teachers and families?

If a country (or internal educational jurisdiction) takes a "status quo" pathway, there is unlikely to be proactive change in policy, programs or practices (although some reactive changes may occur). Of course different countries and educational jurisdictions are on various pathways with respect to the school education of their children with PIMD. For signatories of the UNESCO 2009 Policy Guidelines on Inclusion in Education (and other UNESCO proclamations) this means continuing the pursuit of inclusion as interpreted in that proclamation. Very few jurisdictions claim to have achieved full (or authentic) inclusion as so described (Finland though claim so), but many would explain that subject to the availability of (more) adequate fiscal and human resources, this would be their authentic and achievable goal. Many others aspire to achieve an inclusive school education system (as described) but insufficient resources means "less than" full inclusion has been planned for. Others, who are not signatory to this UNESCO proclamation, might stay a current course that is not synchronous with this proclamation; justified for various political, economic, moral, philosophical, ethical, cultural and/or religious reasons.

A widely cited truism is that understanding the past informs decision making for the future. This paper has presented a brief review of school education for students with PIMD; particularly around the matters of curriculum, pedagogy and assessment. Does this review match your knowledge and understanding; particularly in your national/local context? Does it provide you with a more informed view of the present state of school education for these students? Does this suggest to you what pathway students with PIMD in your jurisdiction would most benefit from in the future? What challenges does this pose for you, particularly with respect to your professional philosophy, ethics, and local policy and practice? Perhaps most importantly, how do we reconcile individual student differences and needs, family preferences and systemic factors in ensuring the achievement of maximized learning outcomes for students with PIMD across their educational life?

Any one pathway is unlikely to fully address the challenges facing these students and their teachers, families and communities; and each would have supporters and critics. It seems timely to discuss this topic within local, national and international forums. Along with our previous paper on this topic we trust the points made above will galvanize such engagement.

\section{Acknowledgements}

This paper has been adapted and extended from Lyons \& Cassebohm (2012). The education of Australian school students with the most severe intellectual disabilities: Where have we been and where could we go? A discussion primer. Australasian Journal of Special Education, 36(1), 79-95.

\section{References}

Arthur-Kelly, M., \& Neilands, J. (2014). Planning Effective Teaching Strategies. In P. Foreman, \& M. Arthur-Kelly (Eds.), Inclusion in Action (4th ed.). Melbourne: Cengage.

Arthur-Kelly, M., Foreman, P., Bennett, D., \& Pascoe, S. (2008). Interaction, Inclusion and Students with Profound and Multiple Disabilities: Towards an Agenda for Research and Practice. Journal of Research in Special Educational Needs, 8, 161-166. http://dx.doi.org/10.1111/j.1471-3802.2008.00114.x

Arthur, M., \& Foreman, P. (2002). Educational Programming for Students with High Support Needs: Report Data from Teachers, Paraprofessionals and Other Professionals Working in Australian Schools. Developmental Disabilities Bulletin, 30, 115-139.

Australian Association of Special Education (2010). The Australian Curriculum. AASE News.

Australian Association of Special Education (2011). President's Report. AASE NSW Chapter Newsletter. 
Australian Teacher Education Association (2006). Making Teaching Public: Reforms in Teacher Education. Proceedings of the 34th Australian Teacher Education Association National Conference, Fremantle.

Bain, A., \& Lancaster, J. (2006). Inclusion and Comprehensive School Reform: Lessons from the Field. Australasian Journal of Special Education, 30, 39-50. http://dx.doi.org/10.1080/10300110609409364

Balandin, S., \& Duchan, J. F. (2007). Communication: Access to Inclusion [Editorial]. Journal of Intellectual \& Developmental Disability, 32, 230-232. http://dx.doi.org/10.1080/13668250701693902

Barber, M. (2011). Communicate, Participate, Enjoy!... Then Communicate Some More! Paper Presented at the SCOPE “Communicate, Participate, Enjoy! Solutions to Inclusion” Conference, Melbourne, Australia.

Bayliss, P. (2005). Peter, Katie and Billy: Including Children with Significant Support Needs. Paper Presented at the ISEC 2005 Conference, Glasgow.

Boyd, B. A., Seo, S., Ryndak, D. L., \& Fisher, D. (2005). Inclusive Education for Students with Severe Disabilities in the United States: Effects on Selected Areas of Outcomes. Paper Presented at the ISEC 2005 Conference, Glasgow.

Brady, L., \& Kennedy, K. (2010). Curriculum Construction (4th ed.). Frenchs Forest: Pearson Australia.

Bray, A., Macarthur, J., \& Ballard, K. D. (1988). Education for Pupils with Profound Disabilities: Issues of Policy, Curriculum, Teaching Methods, and Evaluation. European Journal of Special Needs Education, 3, 207-224. http://dx.doi.org/10.1080/0885625880030403

Browder, D. M., Spooner, F., \& Bingham, M. A. (2004). Current Practices in Alternate Assessment and Access to General Curriculum for Students with Severe Disabilities in the United States of America. Australasian Journal of Special Education, 28, 17-29. http://dx.doi.org/10.1080/1030011040280203

Browder, D. M., Spooner, F., Wakeman, S., Trela, K., \& Baker, J. N. (2006). Aligning Instruction with Academic Content Standards: Finding the Link. Research and Practice for Persons with Severe Disabilities, 31, 309-321.

Brown, R. I., Schalock, R. I., \& Brown, I. (2009). Quality of Life: Its Application to Persons with Intellectual Disabilities and Their Families. Journal of Policy and Practice in Intellectual Disabilities, 6, 2-6. http://dx.doi.org/10.1111/j.1741-1130.2008.00202.x

Carter, M., Stephenson, J., \& Strnadova, I. (2011). Reported Prevalence by Australian Special Educators of Evidence-Based Instructional Practices. Australasian Journal of Special Education, 35, 47-60. http://dx.doi.org/10.1375/ajse.35.1.47

Cook, B. G., Tankersley, M., Cook, L., \& Landrum, T. J. (2000). Teachers’ Attitudes towards Their Included Students with Disabilities. Exceptional Children, 67, 115-135.

Dempsey, I. (2014). Legislation, Policies and Inclusive Practices. In P. Foreman, \& M. Arthur-Kelly (Eds.), Inclusion in Action (4th ed.). Melbourne: Cengage.

Dixon, R. M., \& Verenikina, I. (2007). Towards Inclusive Schools: An Examination of Socio-Cultural Theory and Inclusive Practices and Policy in New South Wales DET schools. Paper Presented at the 2007 Learning and Socio-Cultural Theory: Exploring Modern Vygotskian Perspectives International Workshop, Wollongong University, Wollongong.

Donnelly, V. (2005). Developing an Effective Assessment for Learners with PMLD. Paper Presented at the ISEC 2005 Conference, Glasgow, August 2005.

Dowrick, M. K. (2002). A Model for Assessing Learning Outcomes for Australian Students in Special Schools. British Journal of Special Education, 29, 189-195. http://dx.doi.org/10.1111/1467-8527.00268

European Agency for Development in Special Needs Education (2009). Key Principles for Promoting Quality in Inclusive Education: Recommendations for Policy Makers. Odense.

Ewing, R. (2010). Curriculum and Assessment: A Narrative Approach. Melbourne: Oxford University Press.

Ferguson, D. L. (2008). International Trends in Inclusive Education: The Continuing Challenge to Teach One and Everyone. European Journal of Special Needs Education, 2, 109-120. http://dx.doi.org/10.1080/08856250801946236

Foreman, P., \& Arthur-Kelly, M. (2014). Inclusion in Action (4th ed.). Melbourne: Cengage Learning.

Forlin, C., Loreman, T., Sharma, U., \& Earle, C. (2009). Demographic Differences in Changing Pre-Service Teachers' Attitudes, Sentiments and Concerns about Inclusive Education. International Journal of Inclusive Education, 13, 195-209. http://dx.doi.org/10.1080/13603110701365356

Formosa, L., \& Dixon, R. (2004). The NSW DET’s Quality Teaching Framework and the Realities of a Special Education Classroom. Paper Presented at the 2004 AARE National Conference, Melbourne, December 2004.

Government of Britain (2009). The P Scales: Level Descriptors P1 to P8. London.

Government of Ireland (2006). Quest for Learning: Guidance and Assessment Materials_Profound and Multiple Learning Difficulties. Dublin.

Hall, T. E., Meyer, A., \& Rose, D. H. (2012). Universal Design for Learning in the Classroom; Practical Applications. New York: The Guilford Press. 
Hattie, J. (2012). Visible Learning for Teachers: Maximizing Impact on Learning. London: Routledge.

Hewett, D. (2009). Intensive Interaction: Priorities and Principles for Teaching Communication to Pupils with PIMD. Paper Presented at the 2009 CCEA Conference, England, October 2009.

Imray, P. (2011). The Bridge School Curriculum Document for Pupils with Profound and Multiple Learning Difficulties. Unpublished Manuscript.

Imray, P., Gazquez, D., \& Bond, L. (2010). A PMLD Curriculum for the 21st Century. The SLD Experience, 58, 11-17.

Jones, P. M. (2010). My Peers Have Also Been an Inspiration to Me: Developing Online Learning Opportunities to Support Teacher Engagement with Inclusive Pedagogy for Students with Severe/Profound Intellectual Developmental Disabilities. International Journal of Inclusive Education, 14, 681-696. http://dx.doi.org/10.1080/13603111003778452

Karakoski, J. (2008). The Reform of Education for Students with Special Educational Needs in South Eastern Europe: Lessons and Experiences from Finland's Bilateral Support. Helsinki: Ministry of Foreign Affairs of Finland.

Konza, D. (2008). Inclusion of Students with Disabilities in New Times: Responding to the Challenge. In P. Kell, W. Vialle, D. Konza, \& G. Vogl (Eds.), Learning and the Learner: Exploring Learning for New Times. Wollongong: University of Woolongong.

Loftus, P., Ware, J., \& Donnelly, V. (2005). Developing an Effective Pedagogy for Pupils with PMLD: The Development of a Route Map for Assessing Learners with Multiple Disabilities. Paper presented at the ISEC 2005 Conference, Glasgow, August 2005.

Longhorn, F. (2002). Assessing Happiness for Very Special Learners. The SLD Experience, 33, 21-23.

Lyons, G. (2003). How about a Functional Curriculum? An Alternative Approach to the Education of Students with Profound and Multiple Disabilities. Paper Presented at the 2003 International Congress for School Effectiveness and Improvement, Sydney, January 2002.

Lyons, G. (2010). Quality of Life for Persons with Intellectual Disabilities: A Review of the Literature. In R. Kober (Ed.), Enhancing the Quality of Life of People with Intellectual Disabilities: From Theory to Practice (Social Indicators Research Series, Vol. 41, pp. 73-126). Dordrecht: Springer.

Lyons, G., \& Cassebohm, M. (2010). Life Satisfaction for Children with Profound Intellectual and Multiple Disabilities. In R. Kober (Ed.), Enhancing the Quality of Life of People with Intellectual Disabilities: From Theory to Practice (Social Indicators Research Series, Vol. 41, pp. 183-204). Dordrecht: Springer.

Lyons, G., \& Cassebohm, M. (2011). Curriculum Development for Students with Profound Intellectual and Multiple Disabilities: How about a Quality of Life Focus? Special Education Perspectives, 20, 24-39.

Lyons, G., \& Cassebohm, M. (2012). The Education of Australian School Children with the Most Severe Intellectual Disabilities: Where Have We Gone and Where Are We Going? Australasian Journal of Special Education, 36, 79-95. http://dx.doi.org/10.1017/jse.2012.8

McGill, P., Tennyson, A., \& Cooper, V. (2006). Parents Whose Children with Learning Disabilities and Challenging Behaviour Attend 52-Week Residential Schools: Their Perceptions of Services Received and Expectations for the Future. British Journal of Social Work, 36, 597-616. http://dx.doi.org/10.1093/bjsw/bch297

Morris, I. (2009). Teaching Happiness and Well-Being in Schools: Learning to Ride Elephants. London: Continuum.

Newman, F. M., Marks, H. M., \& Gamoran, A. (1996). Authentic Pedagogy and Student Performance. American Journal of Education, 104, 28-312.

Nietupski, J., Hamre-Nietupski, S., Curtin, S., \& Shrikanth, K. (1997). A Review of Curricular Research in Severe Disabilities from 1976 to 1995 in Six Selected Journals. Journal of Special Education, 31, 36-55. http://dx.doi.org/10.1177/002246699703100104

NSW Disability Discrimination Legal Centre Inc. (2010). Submission: Inquiry into Provision of Education to Students with a Disability or Special Needs. Unpublished Manuscript.

Opertti, R., \& Belalcazar, C. (2008). Trends in Inclusive Education at Regional and Interregional Levels: Issues and Challenges. Geneva: IBE.

Pagliano, P. (2006). The Importance of Humour for Children. Unpublished Manuscript.

Pepper, D. (2007). Assessment for Disabled Students: An International Comparison (QCA Briefing Document). London: Qualifications and Curriculum Authority.

Qualifications and Curriculum Development Agency (2009). Primary Curriculum Review: Curriculum Reform Consultation Report to the DCSF. London: Author.

Qualifications and Curriculum Development Agency (2011). P scales Factsheet. London.

Rogers, C. (2007). Experiencing and "Inclusive” Education: Parents and Their Children with "Special Educational Needs". British Journal of Sociology of Education, 28, 55-68. http://dx.doi.org/10.1080/01425690600996659 
Rowe, K. (2006). Effective Teaching Practices for Students with and without Learning Difficulties: Constructivism as a Legitimate Theory of Learning and of Teaching? http://research.acer.edu.au/learning_processes/10/

Ryndak, D. L., Moore, M. A., Orlando, A. M., \& Delano, M. (2008). Access to the General Curriculum: The Mandate and Role of Context in Research-Based Practice for Students with Extensive Support Needs. Research and Practice for Persons with Severe Disabilities, 33, 199-214. http://0-www.tash.org.library.newcastle.edu.au/publications/ http://dx.doi.org/10.2511/rpsd.33.4.199

Sailor, W. (2008). Access to the General Curriculum: Systems Change or Tinker Some More? Research and Practice for Persons with Severe Disabilities, 33, 249-258. http://0-www.tash.org.library.newcastle.edu.au/publications/

Saloviita, T. (2009). Inclusive Education in Finland: A Thwarted Development. Unpublished Manuscript.

Schalock, R. L. (2010). The Measurement and Use of Quality-of-Life Related Personal Outcomes. In R. Kober (Ed.), Enhancing the Quality of Life of People with Intellectual Disabilities (Chapter 1, pp. 3-320). New York: Springer. http://dx.doi.org/10.1007/978-90-481-9650-0_1

Scruggs, T. E., \& Mastropieri, M. A. (1996). Teacher Perceptions of the Mainstreaming-Inclusion 1958-1995: A Research Synthesis. Exceptional Children, 63, 59-74.

Shearer, J. (2010). Aspects of Quality of Life for Children with a Disability in Inclusive Schools. In R. Kober (Ed.), Enhancing the Quality of Life of People with Intellectual Disabilities: From Theory to Practice (Social Indicators Research Series, Vol. 41, pp. 205-221). Dordrecht: Springer. http://dx.doi.org/10.1007/978-90-481-9650-0_13

Sigafoos, J., Moore, D., Brown, D., Green, V. A., O’Reilly, M. F., \& Lancioni, G. E. (2010). Special Education Funding Reform: A Review of Impact Studies. Australasian Journal of Special Education, 34, 17-35. http://dx.doi.org/10.1375/ajse.34.1.17

Simmons, B., \& Bayliss, P. (2007). The Role of Special Schools for Children with Profound and Multiple Learning Difficulties: Is Segregation the Way? British Journal of Special Education, 34, 19-24.

http://dx.doi.org/10.1080/09620210802351342

Slee, R. (2008). Beyond Special and Regular Schooling? An Inclusive Education Reform Agenda. International Studies in Sociology of Education, 18, 99-116.

Slee, R. (2011). The Irregular School: Exclusion, Schooling and Inclusive Education. Abingdon: Routledge.

Smith, A. (with Jones, J., \& Kurlbaum, J.) (2010). Winning the H Factor: The Secrets of Happy Schools. London: Continuum.

Smith, P. (2007). Have We Made Any Progress? Including Students with Intellectual Disabilities in Regular Education Classrooms. Intellectual and Developmental Disabilities, 45, 297-309. http://dx.doi.org/10.1352/0047-6765(2007)45[297:HWMAPI]2.0.CO;2

Snell, M. (2008). Rethinking Effective Instructional Practices: A Response to Copeland and Cosbey. Research and Practice for Persons with Severe Disabilities, 33, 228-231. http://dx.doi.org/10.2511/rpsd.33.4.228

Soresi, S., Nota, L., \& Wehmeyer, M. L. (2011). Community Involvement in Promoting Inclusion, Participation and SelfDetermination. International Journal of Inclusive Education, 15, 15-28.

http://dx.doi.org/10.1080/13603116.2010.496189

Stephenson, J. (2006). Intellectual Quality for Students with Severe Intellectual Disability. Paper presented at the AARE 2005 International Education Research Conference, Parramatta Campus of the University of Western Sydney, Australia. http://www.aare.edu.au/05pap/ste05118.pdf

Stolk, J., Boer, T. A., \& Seldenrijk, R., Eds. (2011). Meaningful Care: A Multidisciplinary Approach to the Meaning of Care for People with Mental Retardation. Dordrecht: Kluwer Academic.

Taylor, S. J. (1988). Caught in the Continuum: A Critical Analysis of the Principle of the Least Restrictive Environment. Journal of the Association for Persons with Severe Handicaps, 13, 41-53.

UNESCO (2008). Learning Counts: An Overview of Approaches and Indicators for Measuring and Enhancing Quality Learning in EFA-FTI Countries. Paris.

UNESCO (2009). Policy Guidelines on Inclusion in Education. Paris.

Vos, P., De Cock, P., Petry, K., Van Den Noorgate, W., \& Maes, B. (2010). What Makes Them Feel Like They Do? Investigating the Subjective Well-Being in People with Severe and Profound Disabilities. Research in Developmental Disabilities, 31, 1623-1632. http://dx.doi.org/10.1016/j.ridd.2010.04.021

Ware, J., \& Donnelly, V. (2004). Assessment for Learning for Pupils with PMLD: The ACCAC Insight Project. PMLD Link, 16, 12-18.

Watkins, A., Ed. (2007). Assessment in Inclusive Settings: Key Issues for Policy and Practice. Odense: European Agency for Development in Special Needs Education. 
Welsh Assembly Government (2006a). Routes for Learning: Additional Guidance. Cardiff.

Welsh Assembly Government (2006b). Routes for Learning: Assessment Booklet. Cardiff.

Westwood, P., \& Graham, L. (2003). Inclusion of Students with Special Needs: Benefits and Obstacles as Perceived by Teachers in New South Wales and South Australia. Australian Journal of Learning Disabilities, 8, 3-15.

http://dx.doi.org/10.1080/19404150309546718 